\title{
Effect of dietary flaxseed oil level on the growth performance and fatty acid composition of fingerlings of rainbow trout, Oncorhynchus mykiss
}

\author{
Ali Masiha ${ }^{1}$, Nasrollah Mahboobi Soofiani ${ }^{1 *}$, Eisa Ebrahimi ${ }^{1}$, Mahdi Kadivar ${ }^{2}$ and Mohammad Reza Karimi ${ }^{1}$
}

\begin{abstract}
This study evaluated the suitability of flaxseed oil as a source of supplemental dietary lipid for fingerlings of rainbow trout (Oncorhynchus mykiss). Triplicate groups of the 30 fingerlings held under identical culture conditions were fed twice daily by iso-nitrogenous, iso-calorific and iso-lipidic diets for 8 weeks. Experimental diets consisted of $30.2 \%$ protein, $18.6 \mathrm{~kJ} \mathrm{~g}^{-1}$ energy and 16.5\% lipid from fish oil (FO), flaxseed oil ( $\left.F \times O\right)$ and 1:1 blends of the oils (FFX). Moisture, ash, protein, final body weight, specific growth rate, weight gain, feed conversion ratio, survival and hepatosomatic index were not affected by treatments but the percent of lipids was significantly highest in fish fed the flaxseed oil diet (FxOD). The condition factors of fingerlings reared on FxOD and fish and flaxseed oils diet (FFxOD) were significantly lower than those fed the fish oil diet (FOD). Protein efficiency ratio (PER) was significantly higher than those fed the FOD and FFxOD. Whole body fatty acid compositions mirrored those of diet treatments. The highest amounts of highly unsaturated fatty acids (HUFAs) were detected in fish fed $100 \%$ FO, which was significantly different from other treatments. In all treatments polyunsaturated fatty acids/saturated fatty acids (PUFAs/SFAs) and n-6/n-3 ratios were higher than 0.45 and lower than 4 , respectively. Present results indicate the fingerlings can be reared on diets in which $\mathrm{FO}$ has been replaced with $\mathrm{FxO}$, with no significant effects on fish performance.
\end{abstract}

Keywords: Body composition, Fatty acid, Fish oil replacement, Rainbow trout, Vegetable oil

\section{Introduction}

In the course of just a few decades, fish farming has developed into a highly productive and efficient industry to produce animal protein for human consumption. In addition to good growing conditions, a prerequisite for productivity and economic sustainability in fish farming can be a reliable supply of effective feeds. For various reasons, fish meal and fish oil have historically been the dominant raw materials in the production of fish feeds. Due to the development of more energy dense feed types as well as general growth of the aquaculture industry, a significant proportion of the total global fish oil is used for its feed preparation. A lipid requirement equal to $100 \%$ of the world's total fish oil production is estimated by the year 2010 (New, 1999).

\footnotetext{
* Correspondence: soofiani@cc.iut.ac.ir

'Department of Natural Resources, Isfahan University of Technology, Isfahan 84156-83111, Iran

Full list of author information is available at the end of the article
}

While marine oils are superior in their fatty acid composition they also contain a variety of toxic compounds including polychlorinated dibenzo-p-dioxins (PCDD), polychlorinated dibenzofurans $(\mathrm{PCDF})$ and dioxin-like polychlorinated biphenyls (DL-PCB), particularly the nonortho and mono-ortho substituted PCBs (Jacobs et al., 2002a,b; Hites et al., 2004a,b). These compounds are suspected to be carcinogenic and immunosuppressive in humans (Birnbaum and Tuomisto, 2000; Baccarelli et al., 2002; Van Den Heuvel et al., 2002).

It is also well-known that lipid oxidation is one of the major concerns in fish-derived food products. Polyunsaturated fatty acids (PUFAs) are more easily oxidized than saturated fatty acids (SFAs), and therefore, food products enhanced with the PUFAs n-3 are also more prone to lipid oxidation. There is potential human health risks associated with increased consumption of oxidized PUFAs n-3 products (Fritsche and Johnston, 1990; Kubow, 1993). Another important factor to limit a more common use of 
PUFAs n-3 enhanced food products is the development of off-flavors following lipid oxidation that may be offensive to consumers (Waagbø et al., 1993).

While it is obvious that a substitute must be found, replacing fish oil in diets has its own difficulties as most of the vegetable oils are relatively poor sources of $n-3$ fatty acids. Exceptions to this are flaxseed and canola oils which are rich in alpha linolenic acid (18:3n-3) (53\% and $12 \%$, respectively) (NRC, 1993). However, these oils are devoid of longer chain n-3 highly unsaturated fatty acids (HUFAs n-3) and their inclusion in trout diets results in a significant decrease in the tissue levels of eicosapentaenoic acid (20:5n-3, EPA) and docosahexaenoic acid (22:6n-3, DHA) (Bell et al., 2002, 2003a). Moreover, enhancement of omega-3 fatty acid content in rainbow trout fillet was observed in farmed rainbow trout and brook trout as results of flaxseed oil inclusion in diet (Chen et al., 2006; Simmons et al., 2011).

Freshwater fish are capable of converting C18 PUFAs to the longer chain C20 and C22 PUFAs (Henderson and Tocher, 1987) which are the functionally essential fatty acids in vertebrates (Lauritzen et al., 2001).

Several studies conducted on freshwater fish indicated that vegetable oils can successfully replace fish oil in the feed without affecting their survival and growth (Wonnacott et al., 2004; Subhadra et al., 2006). Caballero et al., (2002) reported that in rainbow trout (Oncorhynchus mykiss) up to 80-90\% of vegetable oils e.g. soybean, rapeseed, olive, and palm oils can be used without compromising fish growth. It has also been reported that partial replacement of fish oil by vegetable oils such as rapeseed, soybean, flaxseed or palm oils in fish feeds had no negative impacts on growth and survival of Atlantic salmon (Salmo salar) (Rosenlund et al., 2001), brook char (Salvelinus fontinalis) (Guillou et al., 1995), gilthead sea bream (Sparus aurata), European sea bass (Dicentrarchus labrax) (Izquierdo et al., 2003) and rainbow trout (Greene and Selivonchick, 1990; Caballero et al., 2002).

The aim of the present study was to evaluate the effects of fish oil replacement with flaxseed oil (relatively easily obtained and low priced oil) on growth, feed conversion ratio and fillet fatty acid composition of fingerlings of rainbow trout.

\section{Materials and methods}

270 rainbow trout fingerlings with a mean initial body weight of $16.5 \pm 0.5 \mathrm{~g}$ were purchased from Cheshmeh Dimeh fish hatchery (Shahre kord, Chaharmahal and Bakhtiari, Iran) and used in this study. Prior to the start of the experiment the fish were acclimatized to the new environmental conditions and the commercial diet (SFT2 of Chineh feed production factory, Tehran, Iran) for a two week period within a semi re-circulating system.

\section{Experimental diets}

Three iso-nitrogenous, iso-calorific and iso-lipidic purified experimental diets were formulated from 100\% fish oil (FO), 100\% flaxseed oil (FxO) and 1:1 blends of the two oils (FFxO). The nutritional content and Fatty acid composition of the oils and experimental diets are presented in Tables 1 and 2, respectively. Diets were prepared and stored according to Abery et al., (2002) and De Silva et al., (2002).

\section{Husbandry}

This study was conducted indoors in a thermostatically controlled room. Fish were housed in nine $100 \mathrm{~L}$ fiberglass circular rearing tanks in a semi re-circulating system with an in-line oxygen generator and a physical and biological treatment plant (flow rate of $6 \mathrm{~L} \mathrm{~min}{ }^{-1}$ ). During experiment, fish were kept under a 12-h light: 12 -h dark cycle. The experiment was conducted at $13.6 \pm 1.3^{\circ} \mathrm{C}$, water quality parameters were measured every second day using Aquamerck test kits (Merck, Darmstadt, Germany)

Table 1 Ingredient (\%), proximate composition (\% wet weight) and energy ( $\mathrm{kJ} \mathrm{g}^{-1}$ ) of the experimental diets

\begin{tabular}{|c|c|c|c|}
\hline & FOD & FxOD & FFxOD \\
\hline Fish Meal & 58 & 58 & 58 \\
\hline Soybean Meal & 20 & 20 & 20 \\
\hline Wheat Meal & 8.6 & 8.6 & 8.6 \\
\hline Fish Oil & 8 & 0 & 4 \\
\hline Flaxseed Oil & 0 & 8 & 4 \\
\hline Vitamin premix* & 2 & 2 & 2 \\
\hline Mineral premix** & 1.5 & 1.5 & 1.5 \\
\hline Lysine & 0.07 & 0.07 & 0.07 \\
\hline Methionine & 0.13 & 0.13 & 0.13 \\
\hline Choline chloride & 0.2 & 0.2 & 0.2 \\
\hline Molasses & 1 & 1 & 1 \\
\hline Salt & 0.5 & 0.5 & 0.5 \\
\hline
\end{tabular}

Proximate composition

\begin{tabular}{lccc}
\hline Moisture & 9.80 & 9.10 & 9.63 \\
\hline Ash & 14.59 & 14.76 & 15.29 \\
\hline Crude protein & 30.66 & 30.15 & 29.85 \\
\hline Crude lipid & 16.09 & 16.52 & 16.81 \\
\hline Crude fiber & 2.16 & 2.42 & 2.01 \\
\hline NFE*** & 26.70 & 27.05 & 26.41 \\
\hline Energy*** & 18.56 & 18.71 & 18.57 \\
\hline
\end{tabular}

Diet abbreviations, FOD: 100\% fish oil; FxOD: 100\% Flaxseed oil; FFxOD: 50\% fish oil and $50 \%$ flaxseed oil.

${ }^{*}$ Contains ( $\mathrm{mg} \mathrm{kg}^{-1}$ food): E (30), K (3), niacin (40), thiamine (2), riboflavin (7), pyridoxine (3), folacin (1.5), pantothenic acid (18), biotin (0.7) and cyanocobalamin (0.18).

${ }^{* *}$ Contains (mg kg ${ }^{-1}$ food): Mg (100), Zn (60), Fe (40), Cu (5), Co (0.1), I (1) and Antioxidant (100).

***NFE: nitrogen free extract, calculated by difference $(100-$ moisture - ash crude protein - crude lipid -crude fibers).

****Calculated on the basis of $23.6,39.5$ and $17.2 \mathrm{~kJ} \mathrm{~g}^{-1}$ of protein, fat and carbohydrate, respectively. 
Table 2 Fatty acid composition (percentage of total fatty acids) of the oils and experimental diets

\begin{tabular}{|c|c|c|c|c|c|}
\hline Fatty acid & Fish Oil & Flaxseed Oil & FOD & FxOD & FFxOD \\
\hline 14:0 & 0.06 & - & 0.07 & 0.04 & 0.05 \\
\hline 15:0 & 0.32 & - & 0.23 & 0.09 & 0.17 \\
\hline 16:0 & 20.73 & 6.79 & 22.71 & 16.48 & 19.80 \\
\hline 17:0 & 0.72 & 0.11 & 0.72 & 0.51 & 0.67 \\
\hline 18:0 & 4.16 & 4.48 & 5.85 & 6.04 & 6.20 \\
\hline 19:0 & 2.89 & 1.23 & 2.94 & 2.31 & 2.53 \\
\hline 21:0 & 0.18 & - & 0.25 & 0.24 & 0.29 \\
\hline 22:0 & 0.24 & 0.04 & 0.20 & 0.13 & 0.15 \\
\hline 23:0 & 0.21 & 0.57 & 0.22 & 0.30 & 0.33 \\
\hline 24:0 & 0.18 & - & 0.14 & 0.08 & 0.11 \\
\hline SFAs & 29.68 & 13.22 & 33.32 & 26.22 & 30.29 \\
\hline 14:1 & 3.77 & 0.26 & 3.11 & 1.37 & 2.26 \\
\hline $15: 1$ & 0.80 & 0.07 & 0.71 & 0.38 & 0.56 \\
\hline $16: 1 n-7$ & 5.24 & 0.34 & 4.92 & 2.59 & 3.86 \\
\hline $17: 1$ & 0.71 & 0.06 & 0.65 & 0.27 & 0.41 \\
\hline 18:1n-9 & 33.57 & 34.19 & 38.79 & 41.75 & 40.50 \\
\hline 24:1n-9 & 0.44 & - & 0.41 & 0.14 & 0.26 \\
\hline MUFAs & 44.52 & 34.92 & 48.59 & 46.50 & 47.85 \\
\hline $18: 2 n-6$ & 0.37 & 0.38 & 0.42 & 0.39 & 0.61 \\
\hline $18: 3 n-6$ & 0.05 & - & 0.04 & 0.05 & 0.05 \\
\hline $20: 2 n-6$ & 2.48 & 0.13 & 1.21 & 0.24 & 0.68 \\
\hline $20: 3 n-6$ & 0.18 & - & 0.20 & 0.25 & 0.21 \\
\hline $20: 4 n-6$ & 0.02 & - & 0.06 & 0.03 & 0.05 \\
\hline $22: 2 n-6$ & 0.72 & - & 0.65 & 0.37 & 0.52 \\
\hline $22: 5 n-6$ & 0.36 & - & 0.30 & 0.18 & 0.21 \\
\hline PUFAs n-6 & 4.18 & 0.50 & 2.88 & 1.51 & 2.32 \\
\hline $18: 3 n-3$ & 2.07 & 51.36 & 4.58 & 21.93 & 12.64 \\
\hline $18: 4 n-3$ & 0.32 & - & 0.60 & 0.71 & 0.84 \\
\hline $20: 3 n-3$ & 0.05 & - & 0.61 & 0.05 & 0.05 \\
\hline $20: 5 n-3$ & 5.90 & - & 2.95 & 0.73 & 1.69 \\
\hline $22: 5 n-3$ & 0.48 & - & 0.36 & 0.22 & 0.28 \\
\hline $22: 6 n-3$ & 12.82 & - & 6.65 & 2.16 & 4.05 \\
\hline PUFAs n-3 & 21.62 & 51.36 & 15.75 & 25.80 & 19.55 \\
\hline HUFAs n-3 & 18.72 & - & 9.60 & 2.89 & 5.74 \\
\hline
\end{tabular}

- not detected.

See Table 1 for diet abbreviations.

with a mean $\mathrm{pH}$ of $7.3 \pm 0.2$ and levels of ammonia and nitrate below $0.1 \mathrm{mg} \mathrm{L}^{-1}$.

\section{Experimental protocol}

Two hundred and seventy individually weighed and measured rainbow trout (O. mykiss) fingerlings were randomly distributed into nine $100 \mathrm{~L}$ fiberglass tanks (30 fish per tank) and randomly assigned to one of the 3 different experimental diets (3 replicates for each experimental diet). Fish were fed twice daily at approximately 08.30 and $17.00 \mathrm{~h}$ to apparent satiation for a period of
56 days. At the end of the experiment a sample of 18 fish (2 fish per replicate) was taken and anesthetized in excess anesthetic (Benzocaine $0.5 \mathrm{mg} \mathrm{L}^{-1}$ ) for both body composition and fatty acid profile analysis.

\section{Chemical analysis}

Fishes allocated for flesh analysis were filleted (denuded of skin and bone) and stored at $-20^{\circ} \mathrm{C}$ until used for fillet proximate analysis. Fishes allocated for fatty acids analysis were stored at $-80^{\circ} \mathrm{C}$. Proximate analysis was conducted using standard procedures (AOAC, 1990), percentage moisture (dried at $80^{\circ} \mathrm{C}$ to constant weight), protein (Kjeldahl nitrogen; $\mathrm{N} \times 6.25$ ) in an automated Kjeltech (Model 2300, Tecator, Sweden), total lipid by chloroform/methanol extraction (2:1 v/v) (Folch et al., 1957) as modified by Ways and Hanahan (1964) and ash by incineration in a muffle furnace (Model WIT, C \& LTetlow, Australia) at $550^{\circ} \mathrm{C}$ for $18 \mathrm{~h}$. Fatty acid analysis was carried out on each of the added dietary oils, experimental diets and fillet samples from each of the replicates. Fatty acid methyl esters (FAMEs) were prepared from aliquots of total lipids by acid catalyzed transmethylation with sulfuric acid in methanol overnight at $50^{\circ} \mathrm{C}$ (Christie, 1982). FAMEs were purified by TLC using hexane/diethyl ether/acetic acid (85:15:15 v/v/v) as solvent (Tocher and Harvie, 1988). Separation of FAMEs was carried out in a Gas Chromatograph system (Agilent Technologies, 6890 N, USA) equipped with a flame ionization detector (FID), and a cross-linked silica capillary column HP-88 $(100 \mathrm{~m}, 250 \mu \mathrm{m}$ ID, $0.2 \mu \mathrm{m}$ film thickness), on-column injection and using helium as the carrier gas with a flow rate of $1.1 \mathrm{ml} \mathrm{min}^{-1}$. The column was programmed for an initial temperature of $140^{\circ} \mathrm{C}$ held for $5 \mathrm{~min}$, rising at a rate of $4^{\circ} \mathrm{C} \mathrm{min}{ }^{-1}$ to the final temperature of $240^{\circ} \mathrm{C}$ and held for $10 \mathrm{~min}$. Injector and detector temperatures were $230^{\circ} \mathrm{C}$ and $260^{\circ} \mathrm{C}$, respectively. The flow rates of compressed air and hydrogen were $300 \mathrm{ml} \mathrm{min}^{-1}$ and $30 \mathrm{ml} \mathrm{min}^{-1}$, respectively. Identification and quantification of FAMEs were based on the comparison of the sample retention time with known standards (Sigma Chemicals, St. Louis, USA).

\section{Statistical analysis}

Mean values and standard deviation for each parameter measured for all treatments were calculated first. The results were subjected to a one-way ANOVA to test the effect of the replacement of vegetable oil blends on fish performance. Data were analyzed using statistical packages SPSS v15 (SPSS Inc., Chicago, IL, USA). Differences between means were compared using Duncan's multiple range test at significance of differences $(P<0.05)$ among dietary treatments. Linear regression analyses were performed between dietary and fillet fatty acid concentrations. 


\section{Results}

Growth

The mean final body weight (MFBW) of fingerlings of rainbow trout $(O$. mykiss) ranged from $56.6 \pm 8.0$ to $58.5 \pm$ 14.6 for FxOD and fish and flaxseed oils diet (FFxOD) treatments, respectively. The differences between the MFBW of fish receiving different diets were not significant. Similarly, no significant differences were observed between survival rate, specific growth rate, weight gain, feed conversion ratio and hepatosomatic index. The condition factor of fish reared on FxOD and FFxOD were significantly $(P<0.05)$ lower than those fish fed the FOD. The protein efficiency ratio (PER) was highest in fish fed the FxOD and significantly $(P<0.05)$ higher than those fed with FOD and FFxOD (Table 3).

\section{Fillet proximate composition}

Results of the proximate analysis of fillet of fish receiving the different dietary treatments are tabulated in Table 4. No significant differences between percent moisture, ash and protein content of fish fed the experimental diets were observed, but the percent of lipid content was highest in fish fed the FxOD which was significantly $(P<0.05)$ higher than lipid content of fish fed on FFxOD.

\section{Fillet fatty acid composition}

The major fatty acid classes (SFAs, MUFAs and PUFAs) found in the highest concentration were palmitic, oleic, $\alpha$-linolenic acids along with DHA, respectively (Table 5).

Table 3 Mean $( \pm S D)$ of growth, feed utilisation and other body parameters of rainbow trout reared on the experimental diets

\begin{tabular}{lccc}
\hline & FOD & FxOD & FFxOD \\
\hline MIBW & $16.12 \pm 0.27$ & $16.30 \pm 0.78$ & $16.74 \pm 0.33$ \\
\hline MFBW & $58.05 \pm 6.98$ & $56.56 \pm 8.05$ & $58.52 \pm 14.58$ \\
\hline CF & $1.22 \pm 0.10^{a}$ & $1.15 \pm 0.11^{b}$ & $1.12 \pm 0.10^{b}$ \\
\hline SGR & $2.29 \pm 0.02$ & $2.22 \pm 0.06$ & $2.23 \pm 0.08$ \\
\hline WG & $260.09 \pm 4.25$ & $246.71 \pm 10.78$ & $249.54 \pm 15.23$ \\
\hline FCR & $0.90 \pm 0.17$ & $1.01 \pm 0.05$ & $0.99 \pm 0.30$ \\
\hline SR & $100.00 \pm 0.00$ & $100.00 \pm 0.00$ & $100.00 \pm 0.00$ \\
\hline HIS & $1.21 \pm 0.13$ & $1.14 \pm 0.06$ & $1.15 \pm 0.06$ \\
\hline PER & $1.92 \pm 0.22^{b}$ & $3.12 \pm 0.31^{a}$ & $2.37 \pm 0.16^{b}$
\end{tabular}

Values in the same row with the same superscripts are not significantly different $(P>0.05)$.

See Table 1 for diet abbreviations.

MIBW (g): Mean initial body weight, MFBW (g): Mean final body weight CF: Condition factor $=100 \times($ final weight $(\mathrm{g})) \times(\text { fork length }(\mathrm{cm}))^{-3}$.

SGR $\left(\%\right.$ day $\left.^{-1}\right)$ : Specific growth rate $=[\operatorname{Ln}($ final weight $)-\operatorname{Ln}($ initial weight $)] \times$ (number of days) ${ }^{-1} \times 100$.

WG (\%): Weight Gain $=($ final weight - initial weight $) \times(\text { initial weight })^{-1} \times 100$ FCR: Feed conversion ratio $=($ dry feed fed $) \times(\text { wet weight gain })^{-1}$.

SR (\%): Survival rate $=$ number of fish in each group remaining on day $56-$ (initial number of fish) $)^{-1} \times 100$.

HSI (\%): Hepatosomatic index $=($ weight of liver $) \times(\text { total fish weight })^{-1} \times 100$. PER: Protein efficiency ratio $=($ final weight - initial weight $) \times($ mass of protein (ed) $)^{-1}$.
Table 4 Fillet proximate compositions (mean \pm SD) of rainbow trout reared on different diets, (\% wet weight)

\begin{tabular}{lcccc}
\hline & Initial* $^{*}$ & FOD & FxOD & FFxOD \\
\hline Moisture & $78.44 \pm 0.61$ & $76.96 \pm 0.20$ & $76.48 \pm 1.02$ & $77.39 \pm 0.41$ \\
\hline Ash & $1.34 \pm 0.03$ & $1.28 \pm 0.05$ & $1.36 \pm 0.06$ & $1.28 \pm 0.08$ \\
\hline Protein & $15.29 \pm 0.81$ & $17.77 \pm 0.16$ & $18.55 \pm 1.15$ & $16.49 \pm 1.30$ \\
\hline Lipid & $2.93 \pm 0.20$ & $3.46 \pm 0.27^{\mathrm{a}}$ & $3.48 \pm 0.14^{\mathrm{a}}$ & $2.90 \pm 0.28^{\mathrm{b}}$ \\
\hline
\end{tabular}

See Table 1 for diet abbreviations.

* Statistics not performed on the initial sample.

Values in the same row with the same superscripts are not significantly different $(P>0.05)$

The level of SFAs was observed in higher $(P<0.05)$ concentrations for fish fed the FOD compared to fish fed the FxOD and FFxOD. Levels of MUFAs ranged from $47.4 \pm 0.5$ (FxOD) to $53.0 \pm 0.4$ (FOD) and were observed to be significantly higher in fish fed the FOD. The fillet of fish fed the FOD and FxOD were particularly rich in oleic acid (44.8 $\pm 0.4 \%)$ and $\alpha$-linolenic acid (19.3 $\pm 0.4 \%)$, respectively. DHA and arachidonic acid levels were found in higher concentrations in the fillet than in the diets. The highest level of EPA and DHA was observed in fish fed the FOD $(P<0.05)$. However, DHA was found in high concentrations within all of the dietary treatments, ranging from $5.7 \pm 0.4 \%$ (FxOD) to $10.7 \pm 0.4 \%$ (FOD). The level of n-3 fatty acids was higher in the fillet than the diet for each of the treatments, but the level of n- 6 fatty acids was higher in the fillet than the diet only for FxOD and FFxOD, with $n-6 / n-3$ ratios ranging from $0.12 \pm 0.00$ to $0.16 \pm 0.02$ in the fillet. The highest HUFAs $n-3$ concentrations $(P<0.05)$ were found in fish fed the FOD $(12.8 \pm$ $0.4 \%$ ), while the lowest value was observed in fish fed the FxOD $(6.6 \pm 0.4 \%)$.

Regression analysis was used to identify dose response relationship between dietary and fillet fatty acids. As reported in Table 6 , most of the fatty acid concentrations in the fillet were linearly correlated to the dietary fatty acid concentrations.

\section{Discussion}

The results of the present study suggest that flaxseed oil can be used to replace fish oil without adverse effects on growth performance of rainbow trout fingerlings, as reported in other studies (Montero et al., 2005; Bell et al., 2004; Izquierdo et al., 2005). This was evidenced by the weight gain and feed conversion ratio which ranged from $246.7 \pm 10.8 \%$ to $260.1 \pm 4.2 \%$ and $0.90 \pm 0.17$ to $1.01 \pm$ 0.05 , respectively, with no significant differences from fish fed all experimental diets.

In agreement with previous studies (Caballero et al., 2002; Martino et al., 2002; Glencross et al., 2003; Turchini et al., 2003b), considerable differences were evident in the fatty acid composition of fish fed different lipid sources. For example, there was a high increase in the levels of $\alpha$ - 
Table 5 Fillet fatty acid composition (percentage of total fatty acids) of rainbow trout reared on the different diets (mean \pm SD)

\begin{tabular}{|c|c|c|c|c|}
\hline & Initial & FOD & FxOD & FFxOD \\
\hline $14: 0$ & 0.03 & $0.04 \pm 0.01$ & $0.03 \pm 0.00$ & $0.03 \pm 0.01$ \\
\hline 15:0 & 0.09 & $0.16 \pm 0.01^{a}$ & $0.07 \pm 0.01^{c}$ & $0.10 \pm 0.01^{b}$ \\
\hline $16: 0$ & 10.11 & $17.45 \pm 0.29^{a}$ & $12.46 \pm 0.12^{c}$ & $14.42 \pm 0.26^{b}$ \\
\hline $17: 0$ & 0.14 & $0.50 \pm 0.01^{\mathrm{a}}$ & $0.15 \pm 0.02^{c}$ & $0.37 \pm 0.00^{b}$ \\
\hline 18:0 & 2.90 & $4.46 \pm 0.10^{\mathrm{a}}$ & $4.59 \pm 0.07^{a}$ & $4.27 \pm 0.06^{b}$ \\
\hline 19:0 & 3.07 & $3.72 \pm 0.45^{\mathrm{a}}$ & $2.10 \pm 0.01^{c}$ & $2.94 \pm 0.10^{b}$ \\
\hline 21:0 & 0.21 & $0.19 \pm 0.06$ & $0.26 \pm 0.02$ & $0.19 \pm 0.04$ \\
\hline $22: 0$ & 0.77 & $0.55 \pm 0.06$ & $0.56 \pm 0.08$ & $0.56 \pm 0.04$ \\
\hline 23:0 & 0.72 & $0.28 \pm 0.02^{c}$ & $0.90 \pm 0.08^{\mathrm{a}}$ & $0.67 \pm 0.02^{b}$ \\
\hline $24: 0$ & 0.41 & $0.41 \pm 0.03^{b}$ & $0.72 \pm 0.15^{a}$ & $0.60 \pm 0.03^{a}$ \\
\hline SFAs & 18.44 & $27.74 \pm 0.53^{a}$ & $21.84 \pm 0.20^{c}$ & $24.15 \pm 0.25^{b}$ \\
\hline $14: 1$ & 1.42 & $2.25 \pm 0.08^{\mathrm{a}}$ & $1.10 \pm 0.03^{c}$ & $1.56 \pm 0.05^{b}$ \\
\hline $15: 1$ & 0.17 & $0.52 \pm 0.02^{a}$ & $0.27 \pm 0.00^{c}$ & $0.36 \pm 0.01^{b}$ \\
\hline $16: 1 n-7$ & 1.77 & $4.49 \pm 0.09^{a}$ & $2.35 \pm 0.03^{c}$ & $3.28 \pm 0.09^{b}$ \\
\hline $17: 1$ & 0.18 & $0.48 \pm 0.03^{a}$ & $0.17 \pm 0.13^{b}$ & $0.36 \pm 0.02^{a}$ \\
\hline $18: 1 n-9$ & 61.25 & $44.85 \pm 0.45^{a}$ & $43.25 \pm 0.63^{b}$ & $44.71 \pm 0.15^{a}$ \\
\hline 24:1n-9 & 0.10 & $0.40 \pm 0.03^{\mathrm{a}}$ & $0.27 \pm 0.05^{b}$ & $0.32 \pm 0.01^{b}$ \\
\hline MUFAs & 64.88 & $52.99 \pm 0.38^{a}$ & $47.40 \pm 0.52^{c}$ & $50.60 \pm 0.02^{b}$ \\
\hline $18: 2 n-6$ & 0.71 & $0.41 \pm 0.05$ & $0.52 \pm 0.09$ & $0.42 \pm 0.02$ \\
\hline $18: 3 n-6$ & 0.05 & $0.06 \pm 0.00$ & $0.06 \pm 0.01$ & $0.06 \pm 0.02$ \\
\hline $20: 2 n-6$ & 0.88 & $0.89 \pm 0.06^{c}$ & $1.54 \pm 0.12^{a}$ & $1.11 \pm 0.04^{b}$ \\
\hline $20: 3 n-6$ & 0.13 & $0.09 \pm 0.01$ & $0.07 \pm 0.03$ & $0.08 \pm 0.02$ \\
\hline $20: 4 n-6$ & 0.86 & $0.13 \pm 0.03$ & $0.14 \pm 0.01$ & $0.13 \pm 0.01$ \\
\hline $22: 2 n-6$ & 0.43 & $0.77 \pm 0.07^{\mathrm{a}}$ & $0.65 \pm 0.03^{b}$ & $0.74 \pm 0.02^{\mathrm{a}}$ \\
\hline $22: 5 n-6$ & 0.33 & $0.24 \pm 0.03$ & $0.20 \pm 0.03$ & $0.22 \pm 0.01$ \\
\hline PUFAs n-6 & 3.40 & $2.60 \pm 0.24^{b}$ & $3.18 \pm 0.23^{\mathrm{a}}$ & $2.75 \pm 0.02^{b}$ \\
\hline $18: 3 n-3$ & 4.27 & $1.94 \pm 0.07^{c}$ & $19.35 \pm 0.40^{\mathrm{a}}$ & $10.60 \pm 0.07^{b}$ \\
\hline $18: 4 n-3$ & 2.61 & $1.04 \pm 0.04$ & $1.01 \pm 0.03$ & $1.09 \pm 0.06$ \\
\hline $20: 3 n-3$ & 0.53 & $0.30 \pm 0.03$ & $0.31 \pm 0.04$ & $0.30 \pm 0.01$ \\
\hline $20: 5 n-3$ & 0.87 & $2.08 \pm 0.10^{a}$ & $0.92 \pm 0.05^{c}$ & $1.47 \pm 0.01^{b}$ \\
\hline $22: 5 n-3$ & 0.25 & $0.59 \pm 0.05^{\mathrm{a}}$ & $0.26 \pm 0.04^{c}$ & $0.46 \pm 0.04^{b}$ \\
\hline $22: 6 n-3$ & 4.76 & $10.73 \pm 0.40^{\mathrm{a}}$ & $5.72 \pm 0.39^{c}$ & $8.60 \pm 0.18^{b}$ \\
\hline PUFAs n-3 & 13.28 & $16.67 \pm 0.52^{c}$ & $27.57 \pm 0.72^{a}$ & $22.51 \pm 0.22^{b}$ \\
\hline HUFAs n-3 & 5.63 & $12.80 \pm 0.45^{\mathrm{a}}$ & $6.64 \pm 0.42^{c}$ & $10.07 \pm 0.19^{b}$ \\
\hline PUFAs & 16.68 & $19.27 \pm 0.66^{c}$ & $30.75 \pm 0.57^{a}$ & $25.26 \pm 0.24^{b}$ \\
\hline PUFAs/SFAs & 0.90 & $0.69 \pm 0.04^{c}$ & $1.41 \pm 0.02^{\mathrm{a}}$ & $1.04 \pm 0.02^{b}$ \\
\hline$n-6 / n-3$ & 0.26 & $0.16 \pm 0.02^{\mathrm{a}}$ & $0.12 \pm 0.01^{b}$ & $0.12 \pm 0.00^{b}$ \\
\hline
\end{tabular}

See Table 1 for diet abbreviations.

Values in the same row with the same superscripts are not significantly different $(P>0.05)$

linolenic acid in fish fed either with FxOD and/or FFxOD. As reported by other researchers, (Turchini et al., 2003a,b; Guillou et al., 1995; Bell et al., 2003a, b; Torstensen et al., 2004; Chen et al., 2006; Chen et al., 2008; Simmons et al., 2011), a high correlations are also exist between the individual fatty acids as well as MUFAs and PUFAs of a diet
Table 6 Correlation between dietary fatty acid concentrations and fatty acid concentrations in fillet of rainbow trout fed the experimental diets for 8 weeks

\begin{tabular}{lcc}
\hline Fatty acids & Correlation coefficient $(\boldsymbol{r})$ & Slope \\
\hline $16: 0$ & 0.974 & 0.719 \\
\hline $18: 0$ & 0.451 & 0.201 \\
\hline SFAs & 0.957 & 0.757 \\
\hline $18: 1 \mathrm{n}-9$ & 0.861 & -0.513 \\
\hline MUFAs & 0.997 & 2.637 \\
\hline $18: 2 \mathrm{n}-6$ & 0.537 & -0.274 \\
\hline $20: 4 n-6$ & 0.945 & -0.357 \\
\hline PUFAs n-6 & 0.986 & -0.431 \\
\hline $18: 3 n-3$ & 0.999 & 1.001 \\
\hline $20: 5 n-3$ & 0.999 & 0.521 \\
\hline $22: 6 n-3$ & 0.984 & 1.098 \\
\hline PUFAs $n-3$ & 0.978 & 1.035 \\
\hline PUFAs & 0.982 & 1.287 \\
\hline
\end{tabular}

and the fish fillet (Table 6). There was, however, a high correlation between the amount of SFAs in the diet and SFAs in the fillet, which was not in accordance with the findings of Turchini et al., (2003a,b) who postulated that SFAs were not used efficiently by Murray cod (Maccullochella peelii peelii) as an energy source and were subsequently deposited at an optimal level in preference to the other major fatty acid classes.

It is well known that freshwater fish have a dietary requirement for n-3 and n-6 fatty acids, predominantly in the form of $\alpha$-linolenic and linoleic acids (Kanazawa et al., 1979, 1980; Guillou et al., 1995; Martino et al., 2002; Izquierdo et al., 2003; Tocher, 2003). In comparison to marine fish species, freshwater fish are also generally better adapted to desaturate and elongate these base fatty acids to higher homologs (Guillou et al., 1995; Tocher, 2003). This study observed $\alpha$-linolenic acid in lower concentrations in the muscle than in the diets. It is therefore suspected that a high degree of metabolism of this fatty acid for $\beta$-oxidation and/or desaturation and elongation is taking place in fingerlings of rainbow trout (O. mykiss). This is further bolstered by the presence of $n-3$ desaturation and elongation enzyme products in the form of 18:4n-3 and 20:3n-3 in fish fed FxOD and FFxOD. These fatty acids were found in much lower concentrations in the diets. Likewise, fish fed the FxOD and FFxOD contained n-6 desaturation and elongation intermediates (18:3n-6 and 20:3n-6) and indicate an elongation and desaturation of linoleic acid via $\Delta 6$ desaturase. However, further desaturation of $20: 3 n-6$ to $20: 4 n-6$ and $20: 3 n-3$ to EPA and ultimately DHA was shrouded by high concentrations of these fatty acids within the fillet of initial fish samples. The Department of Health of England (Committee on Medical Aspects of Food Policy 1994) recommends 
a minimum PUFAs/SFAs ratio of 0.45 , and a maximum $\mathrm{n}$ $6 / n-3$ of 4.0 . Table 5 shows that our fish in all treatments met the PUFAs/SFAs and n-6/n-3 ratios. Despite the decrease in EPA and DHA in fillet from fish fed FFxOD, the trout fillets contained a relatively rich source of these fatty acids (584 mg of EPA plus DHA) with a 200 g serving portion of the fillets from fish fed FFxOD. This meets the intake of $500 \mathrm{mg} \mathrm{day}^{-1}$ of EPA plus DHA recommended by the International Society for the Study of Fatty Acids and Lipids (Simopoulos et al., 1999).

\section{Conclusion}

Present study showed the substitution of fish oil with flaxseed oil in the rainbow trout (O. mykiss) diet have been possible without any negative effects on the growth and feed conversion ratio. However, the reflection of the dietary oil source on the fillet fatty acid composition of the fish could be a potential drawback for vegetable oil substitution from a human nutritional point of view, given the decreases in levels of EPA and DHA in fish fed the vegetable oil diets. Further investigation into the benefits of other vegetable oils or indeed a blend of various vegetable oils is required in order to reduce usage of traditionally used fish oils, while simultaneously avoiding a reduction in the human health protective properties found within fish flesh.

\section{Competing interests}

The authors declare that they have no competing interests.

\section{Authors' contributions}

AM: As a MSc student carried out most experimentat work. NMS: As a superviser of MSc give the advise for experimental work and paper preparation. EE: Acted as a co-superviser and helped with MSc work and paper preparation. MK: Helped and advised for fatty acid analysis. MR: Helped with experimental work. All authors read and approved the final manuscript.

\section{Acknowledgements}

This study was funded by the Isfahan University of Technology. The authors thank E. Mottaghi and B. Bahrami for technical assistance throughout the project.

\section{Author details}

'Department of Natural Resources, Isfahan University of Technology, Isfahan 84156-83111, Iran. ²Department of Food Science, College of Agriculture, Isfahan University of Technology, Isfahan 84156-83111, Iran.

Received: 30 September 2012 Accepted: 8 December 2012 Published: 3 January 2013

\section{References}

Abery NW, Gunasekera RM, De Silva SS (2002) Growth and nutrient utilization of Murray cod (Maccullochella peelii peelii) fingerlings fed diets with varying levels of soybean meal and blood meal. Aquac Res 33:279-289

AOAC (1990) In: Helrich K (ed) Official Methods of Analysis of the Association of Official Analytical Chemists. Association of Official Analytical Chemists, Arlington, VA, USA

Baccarelli A, Mocarelli P, Patterson DG, Bonzini M, Pesatori AD, Caporaso N et al (2002) Immunologic effects of dioxin: new results from seveso and comparison with other studies. Environ Health Persp 110:1169-1173

Bell JG, Henderson RJ, Tocher DR, McGhee F, Dick JR, Porter A et al (2002) Substituting fish oil with crude palm oil in the diet of Atlantic salmon (Salmo salar) affects tissue fatty acid compositions and hepatic fatty acid metabolism. J Nutr 132:222-230

Bell JG, Tocher DR, Henderson RJ, Dick JR, Crampton VO (2003a) Altered fatty acid compositions in Atlantic salmon (Salmo salar) fed diets containing linseed and rapeseed oils can be partially restored by a subsequent fish oil finishing diet. J Nutr 133:2793-2801

Bell JG, McGhee F, Campbell PJ, Sargent JR (2003b) Rapeseed oil as an alternative to marine fish oil in diets of post-smolt Atlantic salmon (Salmo salar): changes in flesh fatty acid composition and effectiveness of subsequent fish oil "wash out". Aquaculture 218:515-528

Bell JG, Henderson RJ, Tocher DR, Sargent JR (2004) Replacement of dietary fish oil with increasing levels of linseed oil: modification of flesh fatty acid compositions in Atlantic salmon (Salmo salar), using a fish oil finishing diet Lipids 39:223-232

Birnbaum LS, Tuomisto J (2000) Non-carcinogenic effects of TCDD in animals. Food Addit Contam 17:275-288

Caballero MJ, Obach A, Rosenlund G, Montero D, Gisvold M, Izquierdo MS (2002) Impact of different dietary lipid sources on growth, lipid digestibility, tissue fatty acid composition and histology of rainbow trout (Oncorhynchus mykiss). Aquaculture 214:253-271

Chen YC, Nquyen J, Semmens K, Beamer S, Jaczynski J (2006) Enhancementof omega-3 fatty acid content in rainbow trout (Oncorhynchusmykiss) fillets. J Food Science 71(7):C383-C389

Chen YC, Nguyen J, Semmens K, Beamer S, Jaczynski J (2008) Chemical changes in omega-3-enhanced farmed rainbow trout (Oncorhynchusmykiss) fillets during abusive-temperature storage. Food Control 19(6):599-608

Christie WW (1982) Lipid analysis, 2nd edn. Pergamon Press, Oxford

Committee on Medical Aspects of Food Policy (1994) Nutritional Aspects of Cardiovascular Disease. Department of Health Report on Health and Social Subjects, No. 46, HMSO, London

De Silva S, Gunasekera R, Collins R, Ingram B (2002) Performance of juvenile Murray cod (Maccullochella peelii peelii), fed with diets of different protein to energy ratio. Aquacult Nutr 8:79-85

Folch JM, Lees M, Sloane-Stanley GH (1957) A simple method for the isolation and purification of total lipids from animal tissues. J Biol Chem 226:497-509

Fritsche KL, Johnston PV (1990) Effect of dietary a-linolenic acid on growth, metastasis, fatty acid profile and prostaglandin production of two marine mammary adenocarcinomas. J Nutr 120:1601-1609

Glencross B, Hawkins W, Curnow J (2003) Evaluation of canola oils as alternative lipid resources in diets for juvenile red sea bream (Pagrus auratus). Aquacult Nutr 9:305-315

Greene DHS, Selivonchick DP (1990) Effects of dietary vegetable, animal and marine lipids on muscle lipid and haematology of rainbow trout (Oncorhynchus mykiss). Aquaculture 89:165-182

Guillou A, Soucy P, Khalil M, Adambounou L (1995) Effects of dietary vegetable and marine lipid on growth, muscle fatty acid composition and organoleptic quality of flesh of brook charr (Salvelinus fontinalis). Aquaculture 136:351-362

Henderson RJ, Tocher DR (1987) The lipid composition and biochemistry of freshwater fish. Prog Lipid Res 26:281-347

Hites RA, Foran JA, Carpenter DO, Hamilton MC, Knuth BA, Schwager SJ (2004a) Global assessment of organic contaminants in farmed salmon. Science 303:226-229

Hites RA, Foran JA, Schwager SJ, Knuth BA, Hamilton MC, Carpenter DO (2004b) Global assessment of polybrominated diphenyl ethers in farmed and wild salmon. Environ Sci Technol 38:4945-4949

Izquierdo MS, Obach A, Arantzamendi L, Montero D, Robaina L, Rosenlund G (2003) Dietary lipid sources for sea bream and sea bass: growth performance, tissue composition and flesh quality. Aquacult Nutr 9:397-407

Izquierdo MS, Montero D, Robaina L, Caballero MJ, Rosenlund G, Gine's R (2005) Alterations in fillet fatty acid profile and flesh quality in gilthead sea bream (Sparus aurata) fed vegetable oils for a long term period, recovery of fatty acid profiles by fish oil feeding. Aquaculture 250:431-444

Jacobs MN, Ferrario J, Byrne C (2002a) Investigation of polychlorinated dibenzop-dioxins dibenzo-p-furans and selected coplanar biphenyls in Scottish farmed Atlantic salmon (Salmo salar). Chemosphere 47:183-191

Jacobs MN, Covaci A, Schepens P (2002b) Investigation of selected persistant organic pollutants in farmed Atlantic salmon (Salmo salar), salmon aquaculture feed, and fish oil components of the feed. Environ Sci Technol 36:2797-2805

Kanazawa A, Teshima SI, Ono K (1979) Relationship between essential fatty acid requirements of aquatic animals and the capacity for bioconversion of 
linolenic acid to highly unsaturated fatty acids. Comp Biochem Phys 63B:295-298

Kanazawa A, Teshima SI, Sakamoto M, Awal M (1980) Requirements of Tilapia zilli for essential fatty acids. B Jpn Soc Sci Fish 46:1353-1356

Kubow S (1993) Lipid oxidation products in foods and atherogenesis. Nutr Rev 51:33-40

Lauritzen L, Hansen HS, Jorgensen MH, Michaelsen KF (2001) The essentiality of long chain n-3 fatty acids in relation to development and function of the brain and retina. Prog Lipid Res 40:1-94

Martino RC, Cyrino JEP, Portz L, Trugo LC (2002) Performance and fatty acid composition of surubim (Pseudoplatystoma coruscans) fed diets with animal and plant lipids. Aquaculture 209:233-246

Montero D, Robaina L, Caballero MJ, Gine's R, Izquierdo MS (2005) Growth, feed utilization and flesh quality of European sea bass (Dicentrarchus labrax) fed diets containing vegetable oils: A time-course study on the effect of a refeeding period with a 100\% fish oil diet. Aquaculture 248:121-134

New M (1999) Global aquaculture: current trends of challenges for the $21^{\text {st }}$ century. World Aquac 30:8-13

NRC (National Research Council) (1993) Nutrient Requirement of Fish. National Academy Press, Washington, DC

Rosenlund G, Obach A, Sandberg MG, Standal H, Tveit K (2001) Effect of alternative lipid sources on long-term growth performance and quality of Atlantic salmon (Salmo salar). Aquac Res 32:323-328

Simmons CA, Turk P, Beamer S, Jaczynski J, Semmens K, Matak KE (2011) The effect of a flaxseed oil-enhanced diet on the product quality of farmed brooktrout (Salvelinusfontinalis) fillets. J Food Science 76(3):192-197

Simopoulos AP, Leaf A, Salem N (1999) Workshop on the essentiality of and recommended dietary intakes for omega- 6 and omega- 3 fatty acids. International Society for the Study of Fatty Acids and Lipids. J Am Coll Nutr 18(5):487-489

Subhadra B, Lochmann R, Rawles S, Chen RG (2006) Effect of dietary lipid source on the growth, tissue composition and hematological parameters of largemouth bass (Micropterus salmoides). Aquaculture 255:210-222

Tocher DR, Harvie DG (1988) Fatty acid compositions of the major phosphoglycerides from fish neural tissues: $(n-3)$ and $(n-6)$ polyunsaturated fatty acids in rainbow trout (Salmo gairdneri) and cod (Gadus morhua) brains and retinas. Fish Physiol Biochem 5:229-239

Tocher DR (2003) Metabolism and functions of lipids and fatty acids in teleost fish. Rev Fish Sci 11:107-184

Torstensen L, Frøyland L, Lie O (2004) Replacing dietary fish oil with increasing levels of rapeseed oil and olive oil, effects on Atlantic salmon (Salmo salar) tissue and lipoprotein composition and lipogenic enzyme activities. Aquacult Nutr 10:175-192

Turchini GM, Gunasekera RM, De Silva SS (2003a) Effect of crude oil extracts from trout offal as a replacement for fish oil in the diets of the Australian native fish Murray cod (Maccullochella peelii peelii). Aquac Res 34:697-708

Turchini GM, Mentasti T, Frøyland L, Orban E, Caprino F, Moretti VM et al (2003b) Effects of alternative dietary lipid sources on performance, tissue chemical composition, mitochondrial fatty acid oxidation capabilities and sensory characteristics in brown trout (Salmo trutta). Aquaculture 225:251-267

Van Den Heuvel RL, Koppen G, Staessen JA, Hond ED, Verheyen G, Nawrot TS et al (2002) Immunologic biomarkers in relation to exposure markers of PCBs and dioxins in Flemish adolescents (Belgium). Environ Health Persp 110:595-600

Waagbø R, Sandnes K, Torrissen OJ, Sandvin A, Lie Ø (1993) Chemical and sensory evaluation of fillets from Atlantic salmon (Salmo salar) fed three different levels of $n-3$ polyunsaturated fatty acids at two levels of vitamin $E$. Food Chem 46:361-366

Ways P, Hanahan DJ (1964) Characterization and quantification of red cell lipids in normal man. J Lipid Res 5:318-328

Wonnacott EJ, Lane RL, Kohler CC (2004) Influence of dietary replacement of menhaden oil with canola oil on fatty acid composition of sunshine bass. $N$ Am J Aquacult 66:243-250

doi:10.1186/2193-1801-2-1

Cite this article as: Masiha et al: Effect of dietary flaxseed oil level on the growth performance and fatty acid composition of fingerlings of rainbow trout, Oncorhynchus mykiss. SpringerPlus 2013 2:1.

\section{Submit your manuscript to a SpringerOpen ${ }^{\odot}$ journal and benefit from:}

- Convenient online submission

- Rigorous peer review

- Immediate publication on acceptance

- Open access: articles freely available online

- High visibility within the field

- Retaining the copyright to your article

Submit your next manuscript at $\gg$ springeropen.com 